\title{
COMMENTS
}

\section{BANKS AND BANKING: AUTHORITY OF STATE BANKING SUPERINTENDENT TO CHALLENGE BRANCHING ACTIVITIES OF NATIONAL BANKS}

The Comptroller of the Currency may authorize a national bank to establish a branch when such establishment would be permitted state banks by the local state statute. Competitor banks can challenge the Comptroller's determination alleging noncompliance with the state standard. This comment examines the question of the state's independent ability, proceeding under either state or federal law, to question a ruling by the Comptroller.

$\mathbf{S}_{\text {Ecti }}$ Section 36 (c) of the National Banking Act provides that a national bank may be authorized by the Comptroller of the Currency to establish a branch if a state bank would be authorized to do so under the same circumstances. 1 However, the statute makes no reference to judicial review of the decisions of the Comptroller; ${ }^{2}$ furthermore, although section $36(c)$ incorporates state law, ${ }^{8}$ it fails to indicate whether a state banking official may sue to enjoin a national bank which is acting upon the Comptroller's authority from allegedly violating the state bank-branching law. ${ }^{4}$ Thus the inquiry here will attempt to determine whether the state may enforce its standards for branching upon national banks by suit under either state or federal law. The former alternative raises the issue of the pre-emption of state law by section $36(c)$, while the latter necessitates a discussion of the state's standing to sue under the National Banking Act.

Prior to the passage of legislation specifically authorizing national

I"A national banking association may, with the approval of the Comptroller of the Currency, establish and operate new branches: (I) Within the limits of the city, town or village in which said association is situated, if such establishment and operation are at the time expressly authorized to State banks by the law of the State in question; and (2) at any point within the State in which said association is situated, if such establishment and operation. are at the time authorized to State banks by the statute law of the Statc in question by language specifically granting such authority affrmatively and not merely by implication or recognition, and subject to the restrictions as to location imposed by the law of the State on State Banks. ..." Act of June 16, 1933, ch. 89, § 23, 48 Stat. 189 (1933), as amended, 12 U.S.C. $\$ 36$ (c) (1964).

See note 13 infra and accompanying text.

See note 1 supra.

- Bell, National Bank Branches-The Authority to Approve and to Challenge, 19 Bus. LAw. 887, 911 (1964). 
bank branching, the Supreme Court in First Nat'l Bank v. Missouri ${ }^{5}$ ruled that a state could enforce its law prohibiting branch banking against a national bank. ${ }^{\circledR}$ The Court grounded its decision upon the premise that there was no paramount federal law pertaining to branching with which state law would conflict. ${ }^{7}$ Thereafter, in 1927 Congress enacted the forerunner of section 36 (c), which expressly permitted national banks to establish branches under certain of the limitations imposed by state statutes upon state banking institutions. ${ }^{8}$ The passage of section 36 (c) implemented a congressional design to maintain competitive equality between the state and federal banking systems. ${ }^{9}$ This policy has been under strain in recent years, however, as the Comptroller of the Currency has more actively sought to expand branch banking by national banks, ${ }^{10}$ an endeavor

5263 U.S. 640 (1924). The state attorney general brought a proceeding in the nature of quo warranto in a state court to determine the authority of a national bank to establish a hranch allegedly in violation of state law. Id. at 655 .

- The Court very carefully limited the state's remedy to enforcement of the state banking statute: "The State is neither seeking to enforce a law of the United States nor endeavoring to call the bank to account for an act in excess of its charter powers. What the State is seeking to do is to vindicate and enforce its own law . . . "Id. at 660.

"Id. at 657-59. The relevant federal statutes, REv. STAT. $\$ \$ 5134,5136,5190$ (1875), as amended, 12 U.S.C. $\$ \S 22,24,81$ (1964), did not specifically prohibit any form of branch banking, but the Court found that federal legislation did "not contemplate the establishment of branch banks." 263 U.S. at 658. The Court therefore concluded that state law prohibiting branching would be applicahle: "Having determined that the power sought to be exercised by the bank finds no justification in any law or authority of the United States, the way is open for enforcement of the state statute." Id. at 660 .

${ }^{8}$ Act of Feb. 25, 1927, ch. 191, $\$ 7,44$ Stat. 1228 (1927), as amended, 12 U.S.C. $\$ 36$ (c) (1964). See note 1 supra and accompanying text.

${ }^{9}$ First Nat'] Bank v. Walker Bank \& Trust Co., 87 Sup. Ct. 492 (1966); National Bank v. Wayne Oakland Bank, 252 F.2d 537, 540 (6th Cir.), cert. denied, 358 U.S. 830 (1958); Hoosier State Bank v. Saxon, 248 F. Supp. 233, 236 (N.D. Ind. 1965); Jackson v. First Nat'1 Bank, 246 F. Supp. 134, 140 (M.D. Ga.), rev'd on other grounds, 349 F.2d 71 (5th Cir. 1965); Commercial Sec. Bank v. Saxon, 236 F. Supp. 457, 460 (D.D.C. 1964); Suburban Trust Co. v. National Bank, 211 F. Supp. 694, 697 (D.N.J. 1962); Commercial State Bank v. Gidney, 174 F. Supp. 770, 774 (D.D.C. 1959), aff'd per curiam, 278 F.2d 871 (D.C. Cir. 1960); Handler, Jurisdictional Abstention in Federal. State Branch Bank Conflicts, 19 Rutcers L. Rev. 445, 448 n.19, 450 n.25 (1965).

10 "We have sought by every lawful means to maximize the competitive capacity of banks under our jurisdiction, and we shall continue to do so." Former Comptroller James J. Saxon, quoted in Mr. Saxon's Reply to State Supervisors' Poll, Banking, May 1963, Pp. 157-58. Saxon maintained that the banking systein should be viewed as an instrument of economic expansion. Since most of the policy changes of banking regulation have occurred during periods of economic crisis, he contended that they are ill-suited to meet the needs of the time. Saxon, Bank Expansion and Economic Growth: A New Prospective, 8 ANmTrust Bull. 597 (1964). Thus he sought amendment of the current legislation to free national banks from state branching requirements. Comment, 32 U. CHI. L. REv. 148 n.3 (1964). 
which has often conflicted with the more conservative policies of state officials. ${ }^{11}$ This factor, in addition to more intense economic competition among financial institutions, has led to an increase in litigation under the statute. ${ }^{12}$

Under the terms of the National Banking Act, the only enforcement procedure specifically provided for violations of the statute is a suit brought by the Comptroller. ${ }^{18}$ However, since 1958 it has been clear that a competitor bank has standing to challenge a ruling by the Comptroller as violative of the act. ${ }^{14}$ Whether a state may sue the Comptroller or a national bank to enjoin branching on the theory that it violates either state or federal law has been decided by two federal courts with conflicting results. ${ }^{15}$

II State bankers and state bank supervisors strongly opposed Saxon's efforts to free federal branch banking from the restrictions of state law. See the statement by Robert L. Myers, Jr., President of the National Association of Supervisors of State Banks, in Bratter, How the NASSB Views.Some Current Issues, Banking, Sept. 1962, p. 51. The NASSB represents a large combined membership of state bankers and state banking supervisors. Ibid. According to Myers, "today a primary objective of our association is to resist and stem the present strong trend toward Federal control of the entire banking system, both state and national." Id. at 52.

${ }^{22}$ Bell, supra note 4 , at $887 \& \mathrm{n} .2,888$, observes that increased litigation dates from 1958, when a state bank first successfully enjoined the Comptroller of the Currency from granting a certificate to a national bank to establish a branch. See National Bank v. Wayne Oakland Bank, 252 F.2d 537 (6th Cir.), cert. denied, 358 U.S. 830 (1958).

${ }^{13}$ REv. STAT. \$5239 (1875), as amended, 12 U.S.C. \$93 (1964). This section refers only to action the Comptroller is to take against directors of national banks who violate the statute and is silent about remedies available to an aggrieved party against the Comptroller or a national bank.

1* Alleging irreparable injury to its property, the plaintiff bank may sue either the national bank or the Comptroller. E.g., Whitney Nat'l Bank v. Bank of New Orleans \& Trust Co., 323 F.2d 290, 300 (D.C. Cir. 1963), rev'd and remanded on other grounds, 379 U.S. 411 (1965); National Bank v. Wayne Oakland Bank, 252 F.2d 537, 544 (6th Cir.), cert. denied, 358 U.S. 830 (1958); Commercial Sec. Bank v. Saxon, 236 F. Supp. 457, 458 (D.D.C. 1964); First Nat'1 Bank v. First Nat'l Bank, 232 F. Supp. 725, 728 (E.D.N.C. 1964), rev'd on other grounds, 352 F.2d 267 (4th Cir. 1965); Suburban Trust Co. v. National Bank, 211 F. Supp. 694, 700 (D.N.J. 1962); Commercial State Bank v. Gidney, 174 F. Supp. 770, 780 (D.D.C. 1959).

${ }^{25}$ Compare South Dakota v. National Bank, 219 F. Supp. 842 (D.S.D. 1963), with Jackson v. First Nat'l Bank, 349 F.2d 71 (5th Cir. 1965). Several other cases involving a state suit against the Comptroller or a national bank have not explicitly confronted the standing issue. In Suburban Trust Co. v. National Bank, supra note 14, at 700 n.1, the court specifically declined to express an opinion on the standing of the state attorney general and bank commissioner, since they were joined as plaintiffs with a state bank which had shown irreparable injury. In Texas v. National Bank of Commerce, 290 F.2d 229 (5th Cir.), cert. denied, 368 U.S. 832 (1961), the state challenged the authority of the Secretary of the Treasury to authorize national banks to establish branches on military reservations in Texas, and the court rendered a decision on the merits without raising the question of stariding. When the question of standing arose later in the same circuit it was urged by counsel that the Texas case was of precedential significance on the ground that the question had been contested in the opposing bricfs 
In South Dakota v. National Bank, ${ }^{16}$ the state through its attorney general sued a national bank to enjoin its operation of branches, alleging alternatively violations of state and federal law.. ${ }^{17}$ Citing $M i s-$ souri, the state contended that, since federal law adopted state law as the standard to be applied in branching, there could be no conflict with federal legislation and that the state was the proper party "to enforce and vindicate" its own law. ${ }^{18}$ The federal district court rejected this argument on the ground that Missouri was distinguishable because, after that case was decided, Congress had pre-empted the state legislation by specifically authorizing national banks to establish branches. ${ }^{19}$ In addition, the court ruled that the state could not enforce the paramount federal law because it had neither statutory authority to do $\mathrm{so}^{20}$ nor standing to sue as an injured party. ${ }^{21}$

and that the court could not have decided on the merits, as it did, without having first resolved this threshold issue. Brief for the State of Texas as Amicus Curiae, p. 8, Jackson v. First Nat'l Bank, supra. Without specifically accepting this argument, the court of appeals in Jackson observed that "the authority of the Superintendent to bring an action [was] ... implicit in our decision" in the Texas case. $349 \mathrm{~F} .2 \mathrm{~d}$ at 75.

A state court has denied a state attorney general authority to challenge the establishment of a national bank branch in a quo warranto proceeding on the theory that if branching is permitted under state law, national banks "need look only to the terms of the National Bank Act for guidance and approval of their actions." Rushton v. Michigan Nat'l Bank, 298 Mich. 417, 432, 299 N.W. 128, 134 (1941).

${ }_{10} 219$ F. Supp. 842 (D.S.D. 1963), aff'd on other grounds, 335 F.2d 444 (8th Cir. 1964), cert. denied, 379 U.S. 970 (1965). The question of the state's standing to enjoin an alleged violation of $\S 36$ (c) had become moot on appeal, since the ground upon which standing had been claimed, a State Banking Commission rule, had been declared invalid by the South Dakota Supreme Court in Livestock State Bank v. State Banking Comm'n, 80 S.D. 491, 127 N.W.2d 139 (1964).

${ }^{17}$ The state maintained that violation of the state law constituted a violation of federal law under $\$ 36$ (c). 219 F. Supp. at 845 .

18 Ibid.

10 "The result of the adoption of $\$ 36(\mathrm{c})$ is that there is now paramount federal law on the subject, and thus the states may no longer adopt and enforce their own laws restricting or prohibiting branching by national banks." Id. at 846. A state court has reached the same result. See Attorney General ex rel. State Banking Comm'r v. National Bank, 338 Mich. 610, 614-15, 61 N.W.2d 804, 807 (1953) (state's action dismissed for lack of jurisdiction on same reasoning).

The South Dakota court also noted with apparent approval the defendant bank's contention that since federal jurisdiction was founded on the federal question statute, 28 U.S.C. $\$ 1331$ (a) (1964), adjudication of the dispute as a question of state law would have deprived the court of jurisdiction. $219 \mathrm{~F}$. Supp. at 846 . But see note 33 infra.

${ }^{20} 219 \mathrm{~F}$. Supp. at 848 ; see note 13 supra and accompanying text.

$21219 \mathrm{~F}$. Supp. at 847. The state based its argument as to standing upon the assertion that the national bank branches threatened substantial and irreparable harm to the state, the public, the state banking system, and the state banks. Id. at 844 . The court acknowledged that a state bank threatened with invasion of its property rights would have had standing to sue, but found that the state had failed to show any such threat to the state itself, to a state bank, or to any individual. Furthermore, 
A contrary result was reached more recently by the Fifth Circuit in Jackson v. First Natl Bank. ${ }^{22}$ There the state superintendent of banks sought declaratory and injunctive relief against the defendant national bank, ${ }^{23}$ which was operating a "drive-in facility," allegedly in violation of state law ${ }^{24}$ and thus in noncompliance with the federal statute. $^{25}$ The federal district court in an unreported decision had dismissed the complaint without reaching the merits, ${ }^{28}$ utilizing the federal pre-emption ${ }^{27}$ and lack of standing rationale ${ }^{28}$ of South Dakota. ${ }^{29}$ On appeal, the Fifth Circuit reversed and remanded, hold-

the court expressed doubt that a demonstration of injury to an individual would be sufficient to sustain the state's standing to sue, citing Massachusetts v. Mellon, 262 U.S. 447 (1923). 219 F. Supp. at 847 (dictum).

22349 F.2d 71 (5th Cir. 1965).

${ }^{28}$ The suit was originally brought in a state court, but was removed to the federal district court by the defendant on the theory that that court would have had original jurisdiction under the federal question statute, 28 U.S.C. $\$ 1331$ (a) (1964). Record, pp. 36-37, 41, Jackson v. First Nat'l Bank, 349 F.2d 71 (5th Cir. 1965) [hereinafter cited as Jackson Record]. See 28 U.S.C. $\$ 1441$ (a) (1964).

${ }^{24}$ Since the defendant bank already had its principal office and one branch in Valdosta, the state superintendent of banks contended that the establishment of the drive-in teller facility was a violation of GA. ConE \$ 13-203.1 (c) (Supp. 1966), which limits the branching activity of state banks to one branch in a town the size of Valdosta. Jackson Record 38-39; 349 F.2d at 73. However, an exception to the Georgia statutory branching limitations is provided by a state banking regulation which states that a "Drive-in Teller Facility within the boundary lines of a single contiguous area of property owned and/or leased and occupied as a banking house by such parent bank ... whether physically connected to the main banking house or not . . . shall not be considered an additional bank office, but rather as an expansion of the existing banking house." Ga. Superintendent of Banks Reg. VI (3) (a) (1963), quoted in Jachson Record 39; see 349 F.2d at 73 . In addition, Ga. Superintendent of Banks Reg. VI (3) (b) (1963) provides that a facility located across a street or alley from the main banking house, but connected to it by an overhead passage or an underground tunnel, also will be considered only an expansion. Jackson Record 37-38; see 349 F.2d at 73 .

In the instant case the Comptroller did not issue a certificate authorizing the establishment of a branch, as he is empowered to do by Act of Feb. 25, 1927, ch. 191, §7, 44 Stat. 1228 (1927), 12 U.S.C. $\$ 36$ (e) (1964). See Bell, supra note 4, at 907 \& n.68. Rather, he ruled that no such branching certificate was necessary for the defendant's installation since the alleged branch met the requirements of a drive-in facility, Jackson Record 36, although it was located 281 feet from the principal bank on property not contiguous with the principal office property and not connected to it within the requirements of the regulation. Id. at 40-4I; $349 \mathrm{~F} .2 \mathrm{~d}$ at 73 . Thus, the precise issue being litigated was whether the defendant's facility was a branch under the state statutory definition or an extension of the principal office under the regulatory exception.

${ }^{25}$ Jackson Record 8, 13. The defendant argued that the operation of the facility was solely a matter of federal law to be interpreted and enforced by the Comptroller of the Currency, not by the state banking superintendent. Id. at 31 .

${ }^{20}$ Jackson v. First Nat'l Bank, Civil No. 647 (M.D. Ga., June 30, 1964); Jackson Record 35-46; 349 F.2d at 73 .

${ }^{27}$ Jackson Record 43-44; 349 F.2d at 73.

28 Jackson Record 45.46; 349 F.2d at 73.

${ }^{20}$ See text accompanying notes 16.21 supra. 
ing that the state official could maintain the suit. ${ }^{30}$ However, the ambiguous language of the opinion leaves unclear whether the authority of the state to sue is ultimately founded upon its right to enforce state law or its competency to seek the enforcement of federal law. ${ }^{31}$ The former rationale raises the spectre of federal preemption of state law, the latter the question whether the state has standing to assert noncompliance with the federal statute.

\section{Pre-emption}

Problems of pre-emption immediately arise because of the nature of federal law as a "largely interstitial product, rarely occupying any field completely, building normally upon legal relationships established by the states." 32 However, since the federal government has only partially entered the banking realm, the states have been left with concurrent power to establish and regulate their own banking systems. $^{33}$ A further significant feature of the dual system is that federal law does not purport to regulate every aspect of national banking; state law governs, for example, in the ordinary.business transactions of national banks. ${ }^{34}$

It is clear, however, that, if Congress had authorized national

so "[W]e find that the district court erred in dismissing the complaint for lack of, a proper party plaintiff..." 349 F.2d at 75 .

${ }^{31}$ See notes $39.42,67.68$ infra and accompanying text. Furthermore, it is quite possible to read the Jackson opinion as permitting a state either to bring suit under its own law or to have standing to commence an action under federal law. See 349 F.2d at 73-74; note 39 infra.

${ }^{32}$ Wechsler, The Political Safeguards of Federalism: the Rôle of the States in the Composition and Selection of the National Government, 54 CoLUM. L. REv. 543, 545 (1954).

as "Having . . . discretion not to act at all, Congress $a$ fortiori has discretion to act only for a limited purpose ...." Hart, The Relations Between State and Federal Law, 54 Colum. L. Rev. 489,526 (1954).

While state governments have general regulatory powers over the banks which are chartered under state law, the federal banks are within a separate system that Congress is authorized to establish as an exercise of its enumerated constitutional powers, U.S. CoNST. art. $1, \S 8$, in combination with the necessary and proper clause, U.S. CoNsT. art. $1, \S 8[18]$. McCulloch v. Maryland, 17 U.S. (4 Wheat.) 316, 407, 411-12 (1819): The federal system is independent from state regulation, since the National Banking Act constitutes "by itself a complete system for the establishment and government of national banks ...." Cook County Nat'I Bank v. United States, 107 U.S. 445, 448 (1882).

34 National Bank v. Commonweath, 76 U.S. (9 Wall.) 353, 362 (1869). The traditional rubric has been that a national bank is subject to state law "unless that law interferes with the purposes of its creation, or destroys its efficiency, or is in conflict with some paramount federal law." Lewis v. Fidelity \& Deposit Co., 292 U.S. 559, 566 (1934); see Davis v. Elmira Sav. Bank, 161 U.S. 275, 283 (1896); National Bank v. Commonwealth, supra at 362. 
banks to branch without reference to state law, the states would have been prohibited from requiring national banks to comply with their branching laws, because, in instances of conflict, the supremacy clause of the Constitution ${ }^{35}$ dictates that federal authority will be controlling. ${ }^{36}$ However, since section 36 (c) incorporates state law, it might be inferred that Congress did not intend to preclude the state from enforcing its own law, ${ }^{37}$ which, because of the incorporation, would not logically conflict with the federal law. ${ }^{38}$

In the initial part of its opinion the court of appeals in Jackson appeared to view the problem as one of the enforcement of state law which had not been pre-empted by federal law. ${ }^{30}$ After construing

${ }^{\text {so }}$ U.S. CONST. art. VI, $\$ 2$.

${ }^{\text {so }}$ See Jennings v. United States Fid. \& Guar. Co., 294 U.S. 216, 226 (1935); Davis v, EImira Sav. Bank, 161 U.S. 275, 283 (1896).

${ }^{87}$ Otherwise stated, the question is whether an exercise of state power is compatible with the federal legislation. See note 58 infra and accompanying text. However, the courts have generally approached problems of pre-emption as an attempt to divine what Congress intended, despite the fact that in most instances congressmen probably never anticipated particular problems arising from the interrelationship of state and federal law and consequently never entertained any such collective "intent." Note, 12 STAN. L. REv. 208, 209 (1959). In so doing, the courts have formulated "an often conflicting and frequently unsatisfactory set of rules under which some answer to congressional intent can be given." Hunt, State Control of Sedition: The Smith Act as the Supreme Law of the Land, 41 MinN. L. Rev. 287, 292 (1957). Pennsylvania v. Nelson, 350 U.S. 497 (1956), detailed three of the more frequently mentioned tests of pre-emption, 'namely, whether the scheme of federal regulation is sufficiently comprehensive that no room is left in which the states can operate, id. at 502; whether the federal interest in the field is so dominant that the state will be excluded, id, at 504; and whether the exercise of state power would conflict with the administration of the federal program, id. at 505. However, these "tests" of pre-emption are vague and conclusory and do not indicate the manner in which particular results are reacbed. In fact, the pre-emption cases reflect a bewildering diversity of approaches and results. See Petro, Labor Relations Law, 32 N.Y.U.L. REv. 266, 266-80 (1957); Comment, 1966 DUKE L.J. 484 and cases cited therein. See generally Hunt, supra at 290.99; Note, 12 Stan. L. REv. 208 (1959).

${ }^{85}$ See 349 F.2d at 74. But see notes 58-62 infra and accompanying text.

Cf. Southern Pac. Co. v. Arizona ex rel. Sullivan, 325 U.S. 761, 766 (1945): “Con. gress ... . will not be deemed to have intended to strike down a state statute . . . unless the state law, in terms or in its practical administration, conflicts with the Act of Congress, or plainly and palpably infringes its policy." (Emphasis added.)

${ }_{80}$ "It is conceptually proper to divide the Superintendent's complaint into two brauchès, as the district court apparently did, one challenging the new facility as a violation of state law and the other challenging it as a violation of federal law. The questions for determination under the first branch would be (I) Does the state law purport to apply to national banking associations? and (2) If so, is such application precluded by a pre-emptive federal law? The district court by-passed the first question and answered the second affirmatively. Under the second branch the inquiries would be (1) Is the Superintendent authorized under state law to proceed against national banking associations? and (2) If so, is he precluded from doing so by virtue of federal law? Again the district court went directly to the second question, which it answered affrmatively. We believe the district court erred." 349 F.2d at 73-74. 
the Georgia branch banking statute, the court concluded that "the law of Georgia, resting on its own bottom, would authorize the suit by the Superintendent against a national bank for violation of Georgia's branching laws." 40 The court noted that the Missouri case permitted enforcement of state law where there is no conflict with federal law, ${ }^{41}$ and was constrained to "disagree with the district courts below and in the South.Dakota case that the passage of $\S 36$ (c) has stripped the [Missouri] . . . case of its potency." 42

In asserting that Missouri is still intact even after the passage of section 36 (c), the Jackson court ignored the fact that in Missouri the

${ }^{\circ}$ The assertion that the applicable state statute, GA. ConE ANN. $\$ \$ 13-201,-208$ (Supp. 1966), authorizes the state banking superintendent to proceed against a national bank is a questionable construction of Georgia law. The court reasoned as follows: "Although Ga. Code $\$ 13-201$ expressly excludes national banking associations from the definition of the term 'bank' as used in that Chapter, 'unless the context otherwise indicates,' that section specifically states that 'national banking associations shall have the same, but no greater, rights under or by virtue of this Title and Acts amendatory and supplementary thereof, than is granted to banks and trust companies organized under the laws of this state." 349 F.2d at 74. Apparently the court construed $\$ 13-201$ to mean that national banking associations are to have no greater rights than state banks and trust companies under any circumstances. However, if the words "under or by virtue of this Title and Acts amendatory and supplementary thereof" are given meaning, an alternative reading would be that national banks are to have no greater rights than state banks under the particular Georgia statute. In the instant case the national bank was not asserting rights under the Georgia statute, hut rather riglits from the authority granted it by the Comptroller of the Currency to establish a branch bank. As to whether state branching statutes apply to national banks as a general matter, the Michigan court in Attorney General ex rel. State Banking Comm'r v. National Bank has stated that because of the enactment of $\S 36(c)$, the Michigan branching statute would be invalid to the extent that it purported to apply to national banks. 338 Mich. at 615,61 N.W.2d at 807 .

Iu addition to the disputable statutory construction, Jackson ignored the Georgia Supreme Court's declaration that the state banking statute "was obviously intended to apply only to the State Banks ...." Goodwin v. Citizens \& So. Nat'1 Bank, 209 Ga. 908, 910, 76 S.E.2d 620, 622 (1953).

Furthermore, if the question adjudicated by the court was one of state law, the opinion fails to reveal the theory upon which jurisdiction over the subject matter was founded, since the case was before the court because it raised a federal question. See note 23 supra. This point apparently infiuenced the South Dakota court. See note 19 supra. Undoubtedly the court could liave resolved this jurisdictional problem by asserting ancillary jurisdiction over the non-federal question, even after omitting to decide the federal question, Silver v. Louisville \& Nashville R.R., 213 U.S. 175, 191 (1901), since the same cause of action was alleged alternatively under federal and state law, Hurn v. Oursler, 289 U.S. 238, 245-46 (1933). The court was alerted by the appellee's brief to the problem of enforcing the state claim alone while the case was before it under federal question removal jurisdiction. Brief for Appellee, pp. 3-4, Jackson v. First Nat'1 Bank, 349 F.2d 71 (5th Cir. 1965). Its silence on the issue may indicate that the court was primarily concerned with the application of the federal, rather than the state, statute. See text accompanying notes 67.68 infra.

4349 F.2d at 74. See text accompanying notes 5-7 supra.

1349 F.2d at 74 . 
suit to enforce state law was permitted only after a threshold conclusion that the defendant national bank was not acting under color of explicit federal authority. ${ }^{43}$ It would therefore appear that the Missouri doctrine is limited to enforcement of state law in the $a b$ sence of federal authority and inapplicable to circumstances obtaining after the passage of section 36 (c). Thus, Missouri would be inapposite to sustain-or, for that matter, to prohibit-a suit by the state when there is a federal statute in the field, even though that statute incidentally incorporates state law.

However, the Missouri case is susceptible of alternative readings. For example, it may be interpreted to stand for the proposition that if the federal agency is acting pursuant to express federal authority, state enforcement of its own branching law would create a conflict ipso facto and thus would not be permitted.44 On the other hand, the case may be read to imply that even if express federal authority is present, a further inquiry is necessitated into whether conflict actually arises from the exercise of the two powers. If it does not, then the state could still enforce its law. The Jackson court adopted the second alternative and reasoned that, since the substantive federal terms incorporated those of the state law, there would be no conflict with federal authority if the state enforced its own branching law directly. ${ }^{45}$ This conclusion, clothed in faultless logic, is beguilingly persuasive. It obscures, however, the crucial issue of whether, despite the identity of substantive provisions, this independent exercise of state power may in fact hinder the full implementation of federal policy, a contingency which the doctrine of pre-emption is designed to obviate. ${ }^{46}$

The Jackson court also adopted a theory of implied congressional

4s "The national statutes are interrogated for the sole purpose of ascertaining whether anything they contain constitutes an impediment to the enforcement of the state statute, and the answer being in the negative, they may be laid aside as of no further concern." 263 U.S. at 660.

"See ibid.: "It is insisted that the United States alone may inquire by quo warranto whether a national bank is acting in excess of its charter powers, and that the State is wholly without authority to do so. This contention will be conceded, since it is plainly correct ...."

The view that the passage of $\S 36$ (c) automatically pre-empted state branching law was apparently adopted by the court in South Dakota. 219 F. Supp. at 846.

4s "Since, by virtue of $\S 36(\mathrm{c})$, state law as to branching is federal law applicable to national banking associations, we cannot see how the application of that [state] law would in any way interfere with the operation of national banks or conflict with federal authority." 349 F.2d at 74.

10 See notes 58.62 infra and accompanying text. 
authority to permit suit by a state which had been enunciated by the Supreme Court in First Nat'l Bank v. Fellows ex rel. Union Trust Co. ${ }^{47}$ This case arose under a section of the Federal Reserve Act, ${ }^{48}$ similar in form to the current section 36 (c), ${ }^{49}$ which authorized the Federal Reserve Board to permit national banks to exercise trust and other fiduciary powers where such activity was not in contravention of state law. While the Supreme Court reversed the state court determination that this section of the Federal Reserve Act was unconstitutional, ${ }^{50}$ the Court also denied the defendant national bank's contention that the state court lacked jurisdiction of the proceeding. ${ }^{51}$ Expressly by-passing the defendant's argument that state law had been entirely pre-empted, ${ }^{52}$ the Court held that the state's quo warranto action was valid because the subject matter of the controversy, the exercise of trust powers, was closely related to a normal state function..$^{53}$ It thus implied from the terms of the statute congressional authority for the state court "to consider and pass upon the

17244 U.S. 416 (1917). The state attorney general had brought an action in the nature of quo warranto in the Michigan state court against the defendant national bank, alleging, inter alia, violation of the state's laws governing the exercise of trust powers by banks. The state court held that although no state law had been con. travened, the federal statute authorizing national banks to perform trust functions was invalid on the ground that Congress had exceeded its constitutional powers. Attorney General ex rel. Union Trust Co. v. First Nat'l Bank, 192 Mich. 640, 653-54, 159 N.W. 335, 339-40 (1916), rev'd, 244 U.S. 416 (1917).

is "The Federal Reserve Board shall be authorized and empowered:

....

(k) To grant by special permit to national banks applying therefor, when not in contravention of State or local law, the right to act as trustee, executor, administrator, or registrar of stocks and bonds under such rnles and regulations as the said board may prescribe." Federal Reserve Act, §11, 38 Stat. 261 (1913) (now 12 U.S.C. $\$ 92$ (a) (1964)). (Emphasis added.)

${ }^{4}$ Both provisions sought to improve the competitive position of national banks vis-à-vis state banks by extending to the former a power theretofore reserved to the latter. In each instance the exercise of the power is conditioned upon receipt of approval from a federal administrative authority, and the granting of this approval is in turn conditioned upon the existence of state authority for competitor state banks to engage in the same activity. But see text accompanying notes 58-62 infra for policy differences between the two statutes.

so 244 U.S. at $423-24$.

${ }^{82} I d$. at 428 .

62 Id. at 427 .

ss "[The] subject involves the action of state courts of probate in a universal sense, [and implies] ... from its very nature the duty of such courts to pass upon the question [whether the particular activity was in contravention of state law] and the power of the court below within the limits of state jurisdiction to settle so far as the State was concerned the question for all such courts by one suit, thus avoiding the confusion which might arise in the entire system of state probate proceedings and the very serious injury to many classes of society which also might be occasioued." Id. at 428. 
question whether the particular power was or was not in contravention of the state law . . . ."54

The question of whether the Fellows rationale of implied congressional authority might be used as a ground for a state branching suit brought pursuant to state law was considered in Attorney General ex rel. State Banking Comm'r v. National Bank.55 There the Michigan court found that the trust powers situation was "clearly distinguishable" from the branching issue because "the act of Congress [governing trust powers] provides for a course of action by a Federal agency when and if it is not prohibited by State law, for in such case it is the State law, while in the instant [branching] case it is the act of Congress, which either permits or prohibits the action in question."56 This distinction is specious, however, because under the trust powers statute, just as under the branching law, it is federal legislation which creates the authority that underlies the bank's action.57 Similarly, under both statutes it is the federal administrative agency, not the bank, which is constrained to observe the requirements of state law before the particular power is granted to the national bank. In both instances the state statute effectively applies to national banks by virtue of the incorporation of the state standard into the federal legislation. Thus, there is no logical reason

\footnotetext{
is Ibid.

os 338 Mich. 610, 61 N.W.2d 804 (1953). The question of implied congressional authority was left open by the Missouri case. Although the majority indicated that its decision 'would have been placed on pre-emption grounds if the bank's activity had been specifically authorized by federal law, see note 43 supra and accompanying text, the Court had no occasion to decide the result should the federal legislation incorporate the state standard, as in $\$ 36$ (c). Ironically, the dissent, which argued that the state lacked the capacity to question the exercise of federal authority as to bank branching, 263 U.S. at 668, recognized the Fellows doctrine, enunciated six years earlier, as a possible exception to the general pre-emption rule: "[A]ll the powers of a national bank, like its right to exist at all, have their source in the laws of the United States. Only where those laws bring state laws into the problem,-as by enabling national banks to act as executors, administrators, etc., where that is permitted by state laws,-can the latter have any bearing on the question of corporate power-the privileges which the bank may exercise." Id. at 665-66 (Van Devanter, J., dissenting).

The South Dakota case ignored the possibility of using the Fellows implied con. gressional authority rationale.

se 338 Mich. at 615, 61 N.W.2d at 807. (Emphasis added.)

o7 The fact that the trust powers statute was the national bank's source of authority was clearly shown by the Fellows court when it stated that tbe question was whether the state attormey general could "resort in a state court to proceedings in the nature of quo warranto to test the power of the corporation to exert the particular functions given by the act of Congress . . . 244 U.S. at 427. (Emphasis added.) In fact, state law is of no further importance once it is established that state banks are authorized to exercise trust powers. See note 60 infra.
} 
why a court could not, following Fellows, find implied congressional authority for a state to determine whether branching by a national bank is violative of state law.

The ultimate issue in deciding a question of pre-emption is whether the attempted exercise of state authority impinges upon, or is compatible with, the implementation of federal legislation..$^{58}$ The Fellows result was founded on a consideration that is equally applicable to branching, namely, the desirability of having state courts decide questions of state law to prevent confusion when a federal authority would otherwise have to render its own interpretation of the state's law. ${ }^{59}$ In the trust powers context, the pursuit of this policy objective occasions negligible interference with the administration of the national banks. First of all, the question of whether a state authorizes its banks to exercise particular trust powers is a relatively uncomplicated one, unlikely to give rise to litigation. ${ }^{60}$ Secondly, once decided, the issue will be settled for all banks for all

${ }^{88}$ Hines v. Davidowitz, 312 U.S. 52, 67 (1941); Wham \& Merril, Federal PreEmption: How to Protect the States Jurisdiction, 43 A.B.A.J. 131, 134 (1957); Note, 12 STAN. L. REv. 208, 215 (1959). Whether the rubric is implied congressional authority or pre-emption, a prerequisite to permitting state enforcement of state law against a national bank would be the determination that the state would not be subverting the purpose of the federal banking statute. Thus, if the considerations which led the Fellows court to find implied congressional authority for state suit to enforce trust provisions were present in the branching cases, Fellows might provide authority for holding that state branch banking laws have not been pre-empted by $\$ 36(c)$.

$\Delta 0244$ U.S. at 427-28. Disagreement over the construction of state law has frequently been the center of dispute in the branching cases. In addition to Jackson, see, e.g., Union Sav. Bank v. Saxon, 335 F.2d 718, 721 (D.C. Cir. 1964); Community Nat'l Bank v. Saxon, 310 F.2d 224, 225 (6th Cir. 1962); Commercial State Bank v. Gidney, 174 F. Supp. 770 (D.D.C. 1959).

${ }^{\circ}$ The sole inquiry under the federal trust powers statute is whether state institutions which compete with national banks are authorized by the state to exercise trust powers. If it was ever arguable that the federal statute operated to subject the national banks to any additional or more specific state restrictions, an amendment to the statute in 1918 made this position untenable. Act of Sept. 26, 1918, ch. 177, $\S 2(\mathrm{k}), 40$ Stat. 968 (now 12 U.S.C. $\$ 92(\mathrm{~b})$ (1964)); see Missouri ex rel. Burnes Nat'1 Bank v. Duncan, 265 .U.S. 17, 23-25 (1924). "Whatever may be the state law, national banks having the permit of the Federal Reserve Board may act as executors if trust companies competing with them have that power." Id. at 25.

Furthermore, since Fellows was decided as the first decision under the trust powers statute, only four cases in which a state has been the complaining party have appeared in the federal courts concerning this provision. Ex parte Worcester Nat'l Bank, 279 U.S. 347 (1929); Missouri ex rel. Burnes Nat'l Bank v. Duncan, 265 U.S. 17 (1924); Bates v. Atlantic Nat'l Bank, 101 F.2d 278 (5th Cir. 1939); Fidelity Nat. Bank \& Trust Co. v. Enright, 264 Fed. 236 (W.D. Mo. 1920). However, none of these cases concerned whether the state had authorized its institutions to exercise trust powers. 
occasions so long as the state does not revoke the authority of its own banks to exercise such powers. Thirdly, in the unlikely eventuality that a national bank should erroneously interpret and exercise trust powers in contravention of state law, the burden of complying with the law would be relatively slight when compared with the nullification of the rather considerable investment in a branch bank.

On the other hand, a much greater threat to the administration of the federal banks is posed by continued state enforcement of state branching laws against national banks. Since section 36 (c) incorporates not only the basic state rule relating to the permissibility of branching, but also the state's branch location limitations, ${ }^{81}$ the potential questions raised by the branching statutes are numerous and complex. Every authorization from the Comptroller of the Currency to a national bank to establish a branch would bristle with opportunities for the state to challenge the Comptroller's construc-

-1 See, e.g., Hoosier State Bank v. Saxon, 248 F. Supp. 233, 236 (N.D. Ind. 1965); Bank of Dearborn v. Saxon, 244 F. Supp. 394, 400 (E.D. Mich. 1965). Although $\$ 36$ (c) (2) (relating to branches outside the town of the principal bank) expressly in. corporates state location requirements, $\$ 36(c)(1)$ (dealing with branches inside the municipality of the parent bank) is silent on the point. See note 1 supra; 1965 DUkE L.J. $609,612$.

However, Walker Bank \& Trust Co. v. Saxon, 352 F.2d 90 (10th Cir. 1965), aff'd sub nom. First Nat'l Bank v. Walker Bank \& Trust Co., 87 Sup. Ct. 492 (1966), has clearly established that state requirements are equally applicable under $\$ 36$ (c) (1). In Walker Utah law affirmatively authorized branching within the municipality in which the main office was located but restricted such expansion to takeovers of established banks which had been in operation for five years. UTAH CODE ANN. \$ 7.3.6 (Supp. 1965). Neither of the national banks in Walker complied with the restriction, and certificates issued by the Comptroller were challenged by state banks. The Tenth Circuit held that the Comptroller must "look at all the State law on branch banking, not just part of it." 352 F.2d at 94. The Supreme Court agreed, concluding that if the Comptroller were permitted under $\$ 36$ (c) (1) to look only to state authorization provisions and to ignore the restrictions placed thereon, the well-defined congressional policy of competitive equality would be frustrated. 87 Sup. Ct. at 497 .

The Court also rejected the Comptroller's argument that $\$ 36(c)$ incorporated only state requirements relating to "whether" and "where" branches may be located and not the "method" by which this may be done. "As to the restriction being a 'method,' we have concluded that since it is part and parcel of Utah's policy, it was absorbed by the provisions of $\S 36$ (c) (1) and (2), regardless of the tag placed upon it." Ibid.

Despite the broad language employed by the Tenth Circuit and the Supreme Court in Walker, it seems doubtful that the two courts intended to cast doubt on earlier cases which have held that the approval of a state official is not a prerequisite to establishment of a national bank branch, Rushton ex rel. Commissioner of Banking Dep't v. Michigan Nat'1 Bank, 298 Mich. 417, 299 N.W. 129 (1941), and that state "necessity" or "prospects of successful operation" criteria are not applicable to national banks, American Bank \& Trust Co. v. Saxon, 248 F. Supp. 324, 330 (W.D. Mich. 1965). 
tion of state law and to decide it authoritatively in a different way. ${ }^{02}$ Rather than the serene certainty arising from the definitive declaration on the exercise of trust powers, the result might be a disruptive confusion in the establishment of branch banks. Bankers would possibly be inhibited from proceeding under federal authority in the face of a threat by the state to sue. The state would have, in effect, a veto power over the decisions of the Comptroller, since it could conceivably contest every branching certificate. Thus, although logically the Fellows doctrine would seem to support a state branching challenge, the great difference in the effect on the administration of the national banks arising therefrom casts a serious doubt on the soundness of such a rule.

The chief failing of Jackson in its resolution of the pre-emption question is its glib assumption that there could be no "conflict," im the pre-emption sense, ${ }^{63}$ arising from the continued enforcement of state branching law, since that law is the adopted measuring rod of the federal statute. As suggested above, ${ }^{64}$ there is a strong probability that such conflict would result, a contingency which should have been taken into account before applying the Fellows and $M$ issouri rationales to the branching situation. In order to obviate the problems created by allowing an independent application of state law, perhaps a preferable alternative solution would be to treat the action as one questioning the defendant's federal authority to branch. This course would raise the issue of the standing of the state to challenge the Comptroller's determination of state law under section 36 (c).

o2 Litigation brought by competitor banks challenging the Comptroller's branching certifications has increased in recent years since its inception in 1958. See note 10 supra and accompanying text. A rule allowing states to sue to enforce their statutes directly against national banks could greatly increase this volume of litigation, since the deterring effects of the standing requirement (see generally notes 65-109 infra and accompanying text) and the expense of suing would not be present to discourage the state.

${ }^{63}$ Conflict for pre-emption purposes "does not depend upon the relatively objective textual comparisons of state and federal statutes which a strictly repugnancy test involves. Rather it inquires more broadly into congressional purposes, and looks to see if the state law gives promise of thwarting these objectives." Hunt, supra note 37 , at 294. Cf. Hines v. Davidowitz, 312 U.S. 52, 67 (1941): "Our primary function is to determine whether, under the circumstances of this particular case, Pennsylvania's law stands as an obstacle to the accomplishment and execution of the full purposes and objectives of Congress."

oc See notes 58-62 supra and accompanying text. 


\section{Standing}

Assuming that federal law has pre-empted an independent application of state branch banking provisions and suit is commenced under federal law, or, alternatively, that a state official chooses in the first instance to bring an action under section 36 (c), the threshold issue is necessarily the standing of the state officer to sue under federal law. The doctrine of standing, utilized to determine which parties may sue, encompasses both constitutional requirements and considerations of judicial policy. ${ }^{65}$ The only branch banking case which has considered this issue explicitly is South Dakota, in which standing was denied. ${ }^{68}$ Possibly, however, the issue was decided in Jackson. Despite the references which suggest that the court was enforcing the state branch banking law, ${ }^{67}$ there are conflicting indications that the court actually decided a question of federal law raised under section 36 (c). ${ }^{68}$ If in fact this is what the court intended, the

os Barrows v. Jackson, 346 U.S. 249, 255 (1953). The constitutional requirement limits review to "cases" and "controversies." U.S. CoNsr. art. III, § 2; Massachusetts v. Mellon, 262 U.S. 447, 480 (1923). The policy is based on judicial self-restraint. Barrows v. Jackson, supra at 255. The principal underlying conception is that "the party who invokes the [judicial] power must be able to show not only that the statute is invalid but that he has sustained or is immediately in danger of sustaining some direct injury as the result of its enforcement . . . ." Massachusetts v. Mellon, supra at 488. Although the court in Mellon is referring to standing to challenge legislation on constitutional grounds, the considerations for standing to challenge administrative action are similar. 3 Davis, ADMINISTRATIVE LAW TrEATISE \$22.01, at 210.11 (1958) (hereinafter cited as DAvis). See generally id. $\$ \S 22.01-.18$; Comment, 8 ST. Lours U.L.J. 83 (1963).

${ }^{\circ 6}$ See note 21 supra and accompanying text. Texas v. National Bank of Commerce, 290 F.2d 229 (5th Cir. 1961), ignored the standing issue. See note 15 supra.

${ }^{\circ}$ See notes $39-42$ supra and accompanying text.

68 "T]f such facilities are not authorized to Georgia banks under Georgia law, then, by virtue of $\S 36(c)$, they are not authorized to national banks by the National Bank Act." 249 F.2d at 73. The court said further: "The authority of the Superintendent to bring an action such as that involved in this case was also implicit in our decision in Texas ...." Id. at 75. (Emphasis added.) In Texas, the state was allowed to raise a federal question, although its standing was not specifically considered. See note 15 supra. The clearest statement that federal law was enforced in Jackson appears in the final footnote: "The fact that the Comptroller is charged under 12 U.S.C. $\$ 99$ with the duty of enforcing the National Bank Act certainly does not have the effect of prohibiting actions to enforce that law by any other party who might have a legitimate interest." 249 F.2d at 75 n.1. (Emphasis added.) Additionally, the dicta concerning the plaintiff's standing, see notes 69.71 infra and accompanying text, indicate a question of federal law, since the problem of standing would not exist if state law were being enforced. Furthermore, it is clear that on remand the district court enforced the federal statute. Jackson v. First Nat' Bank, 246 F. Supp. 134, 136-37 (M.D. Ga. 1965). This is not conclusive as to the intention of the court of appeals, however, because on remand the suit was consolidated with another action brought on the same cause by a competitor bank, making the superintendent's standing moot. Id. at 136. Finally, the case was removed to the federal courts under the federal question removal statute. See note 23 supra. 
only grounds for the state superintendent's standing advanced by the court are the assertions that he is "particularly well situated to represent interests adverse to those of a national bank," strongly motivated to see to it that national banks adhere to the substantive state standard than is the Comptroller, ${ }^{70}$ and, by implication, that he has a "Iegitimate interest' 'in maintaining the suit. "I

Traditionally, the test of standing has been whether some "legal right" of the complaining party has been invaded, ${ }^{72}$ a requirement which has normally been determinable upon a demonstrated irreparable injury or the threat thereof. ${ }^{73}$ A state is ordinarily treated as a private litigant for purposes of standing; however, some showing of economic injury is generally required. ${ }^{74}$ Nevertheless, an allegation of economic detriment to the state arising from the Comptroller's excessively liberal construction of state branching statutes and the consequent relative ease with which federal banks could branch is probably too tenuous to be judicially cognizable. ${ }^{75}$ As parens patriae, the state may under some circumstances bring suit on behalf of its

249 F.2d at 75 .

70 Id. at 75 n.I.

72 Ibid.

72 See Tennessee Elec. Power Co. v. TVA, 306 U.S. 118, 137-38 (1939).

${ }^{73}$ Perkins v. Lukens Steel Co., 310 U.S. 113, 125 (1940). Recent decisions have allowed standing even when the alleged prpoerty injury was indirect, see Columbia Broadcasting System v. United States, 316 U.S. 407, 422-23 (1942) (contractual relationships affected by administrative order); Frost v. Corporation Comm'n, 278 U.S. 515, 519-21 (1929) (owner's business affected by grant of franchise to competitor) or future, see United States v. Storer Broadcasting Co., 351 U.S. 192, 199-200 (1956) (planning of future operations affected). However, such injury must be to a particular right of the litigant, and vindication of the general public interest in the administration of the law has been held insufficient to sustain standing of a private litigant. Perkins v. Lukens Steel Co., supra.

"See, e.g., cases cited note 75 infra. Compare City of Atlanta v. National Bituminous Coal Comm'n, 308 U.S. 517, affirming 26 F. Supp. 606 (D.D.C. 1939) (city lacked standing to sue), with Associated Indus. v. Ickes, 134 F.2d 694 (2d Cir.), rev'd on other grounds, 320 U.S. 707 (1943) (injured consumer allowed to sue). Standing was denied in South Dakota because no injury to the state's property rights had been shown. See note 21 supra and accompanying text.

${ }_{75}$ Even if competitive inequality" caused a financial Ioss to state banks or encouraged them to migrate into the federal system, this would not demonstrate an economic injury to the state. The reason is that the state has no ownership interest in state banks; it merely charters and regulates them.

Furthermore, the cases in which the state's standing has been grounded upon economic injury have been those where the Court could label the state a proprietor, e.g., Georgia v. Tennessee Cooper Co., 206 U.S. 230, 237 (1907) (owner of real property), or where the injury was direct and tangible, e.g., Oklahoma v. Civil Service Comm'n, 330 U.S. 127, 136-37 (1947) (loss of federal highway funds). But see Georgia v. Pennsylvania R.R., 324 U.S. 439 (1945) (state "proprietary interest" as railroad owner treated "merely as a "makeweight" "). 
citizens, ${ }^{78}$ but it must show that the interest asserted is shared by its citizens generally and that the suit is not simply for the benefit of private parties. ${ }^{77}$ Yet the state's capacity to sue as parens patriae has usually been limited to controversies involving private parties or other states as defendants, ${ }^{78}$ and Massachusetts $v$. Mellon ${ }^{70}$ expressly held that in relation to a federal taxing statute the federal government, not the state, stands as parens patriae..$^{80}$

No case has yet specifically articulated the interest which the state is asserting in the branch banking situation that deserves judicial protection. ${ }^{81}$ Obviously, however, the state is intimately concerned with the preservation of those instrumentalities which it has created. This concern has been implicitly recognized by the statutorily created federal policy to maintain competitive equality between state and national banks ${ }^{82}$ which is threatened by the likelihood that state banks will convert into national institutions should expansion become easier in the federal system. ${ }^{83}$ Thus the significant question is whether migration of state banks into the federal system, encouraged by the Comptroller's misconstruction of the state branching statute, is sufficient injury for the state to be given standing to challenge the rulings of the Comptroller.

In Hopkins Fed. Sav. \& Loan Ass'n v. Cleary, ${ }^{84}$ the Wisconsin State Banking Commissioner sued to challenge a federal statute ${ }^{85}$ which

$7^{6}$ See, e.g., id. at 445; Kansas v. Colorado, 185 U.S. 125, 142 (1902).

"7 Oklahoma ex rel. Johnson v. Cook, 304 U.S. 387, 396 (1938); Pennsylvania v. West Virginia, 262 U.S. 553, $591-92$ (1923); Land O'Lakes Creameries, Inc. v. Louisiana State Bd., 160 F. Supp. 387, 389 (E.D. La. 1958).

${ }^{78}$ See, e.g., cases cited in notes 76-77 supra.

тө 262 U.S. 447 (1923).

${ }^{80} \mathrm{Id}$. at 486 . Thus, clearly the South Dakota court was correct when it suggested that a showing of injury to its citizens would not be sufficient to give the state standing to sue under $\$ 36(\mathrm{c})$. $219 \mathrm{~F}$. Supp. at 847.

81 The plaintiff in South Dakota has come the closest to defining a state interest in federal branch banking. See note 21 supra. A showing of sufficient interest is crucial, because "if no comparable common-law right exists and no such constitutional or statu. tory interest has been created, relief is not available judicially." Joint Anti-Fascist Refugee Comm. v. McGrath, 341 U.S. 123, 152 (1951) (concurring opinion).

82 See note 9 supra and accompanying text.

${ }^{83} \mathrm{~A}$ bank incorporated under state law may convert into a national banking associa. tion with the vote of shareholders owning fifty-one per cent of the stock and upon the approval of the Comptroller of the Currency. REv. STAT. $\$ 5154$ (1875), as amended, 12 U.S.C. $\$ 35$ (1964). The number of state-to-federal conversions has increased significantly in the past decade. See Banking, Aug. 1965, p. 60.

Bะ 296 U.S. $315 \cdot$ (1935).

B5 Federal Home Loan Bank Act $\S 4$ (a), 47 Stat. 726 (1932), as amended, 12 U.S.C. $\S 1424$ (a) (1964). 
permitted state building and loan associations to convert into federal savings and loan associations. In holding the statute unconstitutional to the extent that it permitted conversion when unauthorized by state law, ${ }^{86}$ the Court founded the state's standing upon the encroachment on its reserved constitutional powers, "an invasion of sovereignty or quasi-sovereignty" of the state, 87 and upon its relation as parens patriae. ${ }^{88}$ The Court was careful to distinguish this case from Massachusetts $v$. Mellon on the ground that in Hopkins the alleged transgressor of state law was a corporation created by the state rather than a federal instrumentality. ${ }^{89}$ This distinction was the ground upon which South Dakota distinguished Hopkins. ${ }^{90}$ Yet this differentiation should not be pressed uncritically, for despite the fact that the defendant association had been chartered by the state, ${ }^{91}$ the significant point is that Hopkins allowed a state, on the basis of its interest in preserving its own institutions, ${ }^{92}$ to challenge a federal statute under the authority of which the defendant institution was defecting from the state system. It thus follows that upon a showing of similar injury, a state could cite Hopkins as authority

\footnotetext{
so 296 U.S. at 335 .

${ }^{87}$ Id. at 337. The Court found that the interest asserted by the state was a reserved power under the tenth amendment to the Constitution. Subsequent to Hopkins, the Court declared the tenth amendment to be "but a truism that all is retained which has not been surrendered," and that consequently "all means for the exercise of a [federal] granted power which are appropriate and plainly adapted to the permitted end" will be upheld as constitutional. United States v. Darby, 312 U.S. 100, 124 (1941). However, this shift in constitutional emphasis does not necessarily affect the authority of Hopkins on the standing issue. In the first instance, the Court in Hopkins expressly disclaimed the notion that the decision was based upon the scope of federal power. 296 U.S. at 343. Secondly, conceding that the state has no reserved power in the face of a legitimate exercise of federal authority, nevertheless the continued recognition of the state's constitutional interest for the purpose of standing is necessary to preserve the opportunity for the legitimacy of the exercise of federal power to be raised for determination in a judicial proceeding.

${ }^{88} \mathrm{Id}$. at 340 .

oo "The ruling [in Massachusetts $v$. Mellon] was that it was no part of the duty or power of a state to enforce the rights of its citizens in respect of their relations to the Federal Government. . . . Here, on the contrary, the state becomes a suitor to protect the interests of its citizens against the unlawful acts of corporations created by the state itself." Id. at 341 .

${ }^{\circ 0} 219$ F. Supp, at 847-48.

${ }^{21}$ However, when the suit was brought, the defendant had taken all the steps necessary under the statute to become a federal institution, 296 U.S. at 327, 331, and, as such, was subject to federal authority.

${ }^{02}$ State building and loan associations "haye been given corporate capacity in the belief that their creation will advance the common weal. The state, which brings them into being, has an interest in preserving their existence, for only thus can they attain the ends of their creation." Id. at 336-37. (Emphasis added.)
} 
for its standing to challenge a determination by the Comptroller under section 36 (c). Although this line of argument is made more tenuous by the fact that the injury to the state results only indirectly from the violation of the branch banking statute, ${ }^{93}$ the primary policy consideration is the same in both instances, namely, that the federal government ought to be prohibited from unlawfully enticing state-chartered institutions into its own system.

Of possible assistance to the state banking supervisor is the Administrative Procedure Act, ${ }^{94}$ which provides for review of administrative action taken under statutes otherwise lacking review provisions. ${ }^{95}$ By its terms the statute excludes review of "agency action

\footnotetext{
${ }^{23}$ A logical difficulty arises because in the conversion itself, which does injury to the state interest, $\S 36$ (c) is not violated, and conversely, the violation of $\S 36(\mathrm{c})$ does not itself injure a state interest unless it is related to the loss of a state bank to the federal system through conversion. Actually, both elements were present in South Dakota, where the violation alleged was the merger of the defendant national bank with three state banks and the continued operation of the latter as branches of the parent contrary to the terms of the state branching statute. $219 \mathrm{~F}$. Supp. at 844 . However, the court found Hopkins to be distinguishable. See notes 89-90 supra and accompanying text. For a clear instance in which branching privileges have been extended by the Comptroller where they would not have been by the state authority, see discussion of Camden Trust Co. v. Gidney, 301 F.2d 521 (D.C. Cir. 1962), in Handler, Jurisdictional Abstention in Federal-State Branch Bank Conflicts, 19 RuTGERs L. REv. $445,450-51$ (1965). Such conflicts and the increase in conversions from state to federal banks in recent years, note 83 supra, lend plausibility to the argument that the state banking systems are being injured by the Comptroller's liberal branching policy. At least one instance is reported in which the state authority denied a request for branching approval, whereupon conversion followed and the desired branch was authorized by the Comptroller. See Banking, Aug. 1965, p. 62.

of "Except so far as (1) statutes preclude judicial review or (2) agency action is by law committed to agency discretion-(a) Right of review.

"Any person suffering legal wrong because of any agency action, or adversely affected or aggrieved, by such action within the meaning of any relevant statute, shall be entitled to judicial review thereof." Administrative Procedure Act $\S 10,60$ Stat. 243 (1946), 5 U.S.C. $\$ 1009$ (1964). (Emphasis added.)

${ }^{\circ}$ See 3 Davis $\$ 22.04$, at 221. As the Administrative Procedure Act represented a compromise of widely divergent points of view, there has been some uncertainty as to its effect on pre-existing law. See the summation of the legislative history and purpose of the act in Wong Yang Sung v. McGrath, 339 U.S. 33, 36-41 (1950), which suggests that substantive changes in the law were effected. Id. at 40-41. In a very thorough article, Professor Berger argues that a right to review is conferred by the act. Berger, $A d$ ministrative Arbitrariness and Judicial Review, 65 Colum. L. REv. 55, 92 (1965). Contra, 4 Davis \$19.07, at 41.42; Jaffe, The Right to Judicial Review, 71 Harv. I. REv. 769, 790-91 (1958) (the act merely codifles the existing presumption of reviewability). Apparently the Supreme Court agrees that the act has at least expanded the right to judicial review. Compare Heikkila v. Barber, 345 U.S. 229, 232 (1953) (Court denied review but nevertheless expressed "a judicial attitude of hospitality towards the claim that $\$ 10$ greatly expanded the availability of judicial review"), with Shaughnessy v. Pedreiro, 349 U.S. 48, 51 (1955) (under essentially the same circumstances Court permitted review as a course "more in harmony with the gen. erous review provisions of the Administrative Procedure Act”).
} 
[that] is by law committed to agency discretion." ${ }^{86}$ On its face this would seem to preclude review of the bank branching cases, as branching certificates are by law granted within the discretion of the Comptroller. ${ }^{97}$ However, the APA has not been construed literally, and it is clear that the presence of administrative discretion does not foreclose review of action taken by the governmental agency, ${ }^{98}$ a proposition borne out by the branching cases themselves.99 Despite the fact that a right of review is secured, however, the standing requirement must still be met. ${ }^{100}$ In this regard the act has probably

'See note 94 supra.

${ }^{97}$ See note 1 supra.

${ }^{98}$ See United States v. Shimer, 367 U.S. $374,881-82$ (1961) (no review of discretionary act unless the administrator exceeded his authority or acted wrongly); Harmon v. Brucker, 355 U.S. 579 (1958) (exceeding statutory powers does not constitute an exercise of administrative discretion); Adams v. Witmer, 271 F.2d 29, 33 (9th Cir. 1958) ("The exercise of discretion by the agency does not in itself negative the right to judicial review.")

Davis contends that regulation of national banks is confined exclusively to the supervisory power of the regulatory agencies and is largely immune from judicial review. 1 DAvIs $\$ 4.04$, at $247-51$. Nevertheless, this view has not prevailed in the courts. In Community Nat'l Bank v. Gidney, 192 F. Supp. 514 (E.D. Mich. 1961), aff'd sub nom. Community Nat'l Bank v. Saxon, 310 F.2d 224 (6th Cir. 1962), the district court, citing Davis, 192 F. Supp. at 518, ruled that the case fell within the "committed to agency discretion" exception of the Administrative Procedure Act, thereby rendering the Comptroller's decision unreviewable. Id. at 519. However, the court of appeals discloses that in a later ruling, unreported and given orally, the district court held that the Administrative Procedure Act did apply, but found that the Comptroller had not abused his discretion. 310 F.2d at 225-26. The court of appeals affirmed without specifically discussing whether the case fell within the statutory exception in view of the Comptroller's discretion. Id. at 226-27.

In its initial holding, the district court had given as its primary reason for excepting the Comptroller's decision from review the failure of Congress to set out within $\$ 96$ (c) standards by which arbitrariness could be judged by the court. However, this fact should not be controlling, because Congress has apparently never provided standards of reasonableness or arbitrariness, and it is the function of courts to make this very sort of determination. Berger, supra note 95, at 77-78. Davis argues that in the banking area, "factors other than formal procedures or judicial review" are available as a curb on the exercise of administrative power by the Comptroller, but he does not specify what these various factors are. 1 Davis $\$ 4.04$, at 251 . Apparently in the branch banking cases no extrajudicial remedy is available to an aggrieved party, for no record has been found of any other form of recourse. It is felt that correction through the political process is unpromising. Berger, supra note 95, at $80-81$.

${ }^{\circ}$ In addition to Community Nat'l Bank v. Gidney, supra note 98, see Bank of Dearborn v. Saxon, 244 F. Supp. 394 (E.D. Mich. 1965); First Nat'l Bank v. First Nat'I Bank, 232 F. Supp. 725 (ED.N.C. 1964), rev'd on other grounds, 952 F.2d 267 (4th Cir. 1965). Other cases have reviewed and overturned rulings of the Comptroller without the use of the Administrative Procedure Act. Peoples Bank-Trenton v. Saxon, 244 F. Supp. 389, 394 (E.D. Mich. 1965) (Comptroller's reading of the state statute was arbitrary, capricious, and an abuse of discretion); Commercial Sec. Bank v. Saxon, 236 F. Supp. 457, 459 (D.D.C. 1964) (Comptroller has "no discretion to unlawfully issue a certificate.")

${ }^{200}$ See notes $94-95$ supra. The language of $\$ 10$ of the APA indicates that the 
left the pre-existing law unchanged, ${ }^{101}$ although the argument has been advanced that the statute has relaxed the standing limitation. ${ }^{102}$ However, the act has not as yet been relied upon in a branch banking case as a ground for standing.

Because the state's interest is basically public and regulatory as opposed to private or proprietary, it may be difficult to establish a rationale to support the standing of a state to seek the enforcement of section 36 (c) under the traditional tests. ${ }^{103}$ Unless the state can show the invasion of an interest which merits judicial protection, as was done in Hopkins, ${ }^{104}$ the congressional deference to state interests represented by the incorporation of state law into section 36 (c) will not alone provide standing, despite the fact that no other remedy is available to restrain the Comptroller from indirectly violating state law. ${ }^{105}$ Thus, South Dakota was on secure legal footing in denying

traditional requirement of "legal wrong". continues to apply unless the detriment alleged is protected by statute.

${ }_{101}$ Kansas City Power \& Light Co. v. McKay, 225 F.2d 924, 931-33 (D.C. Cir.), cert. denied, 350 U.S. 884 (1955) (act adopted existing law on standing); Atchison T. \& S.F. Ry. v. United States, 130 F. Supp. 76, 78 (E.D. Mo.), aff'd per curiam, 850 U.S. 892 (1955).

${ }^{102}$ Davis contends that the statute provides review for anyone who is in fact adversely affected by an administrative decision. 3 DAvis $\$ 22.02$. Berger argues that the statute departs from prior law in that, while adverse personal effect and unlawful conduct are still required, invasion of a "legal right" is not. Berger, supra note 95, at 85.88. However, no cases have been found to support this view.

${ }^{108}$ The cases in which the courts have been most generous in relaxing the requirements for standing have been those in which a distinctly personal right was asserted, e.g., Shaughnessy v. Pedreiro, 349 U.S. 48 (1955) (alien under deportation order); Barrows v. Jackson, 346 U.S. 249 , 255-59 (1953) (plaintiff permitted to assert constitutional rights of a third party), or, when the right was less personal, those in which it could be rationalized as proprietary, e.g., Adams v. Witmer, 271 F.2d 29, 32-33 (9th Cir. 1958) (review permitted on ground that plaintiff's mining claim was a property right).

104 See text accompanying note 92 supra.

${ }^{105}$ However, where injury has been established, the fact that no other remedy is available may influence the decision to allow the plaintiff to sue. See, e.g., Commercial State Bank v. Gidney, 174 F. Supp. 770, 778 (D.D.C. 1959), aff'd per curiam, 278 F.2d 871 (D.C. Cir. 1960); cf. Utah Fuel Co. v. National Bitmuminous Coal Comm'n, 306 U.S. 56,60 (1989) (plaintiff allowed to sue partly because of lack of other remedy). Lack of another remedy influenced the Hopkins court to find standing. See 296 U.S. at 339.

The state could argue that there is no other remedy available when there is no competitor bank within the trading area which could bring the suit. In Jackson this condition did not exist, because after the district court judgment a Georgia state bank brought a separate suit on the same cause of action, which was consolidated with Jackson upon its remand from the court of appeals, whereupon judgment was rendered for the plaintiffs. Jackson v. First Nat'1 Bank, 246 F. Supp. 134 (M.D. Ga. 1965). On the other hand, there was no state bank in the competitive area available to act as plaintiff in the South Dakota case. Letter from Mr. Horace R. Hansen, amicus curiac on behalf of the Independent Banker's Association of America to the Duke Law Journal, Oct. $12,1965$. 
the state standing, and Jackson faltered when it suggested that adverse interest bolstered by strong motivation was sufficient to allow the state to sue. ${ }^{108}$ However, it may well be that traditional concepts, literally and mechanically applied, are inadequate to meet the challenge of misinterpretation of state law by federal authorities to the detriment of state institutions. Thus, in the future there may be a greater tendency to find a sufficient state interest by courts which have grown apprehensive about the sometimes insensitive application of state law by the Comptroller, ${ }^{10 r}$ whose self-avowed policy of expansion has deliberately conflicted with the more conservative policies of many of the states. ${ }^{108}$ When the court feels that the Comptroller is flouting the law, it may be less inclined to let the flexible doctrine of standing-which has been conveniently ignored in the service of judicial expediency ${ }^{109}$-stand in the way of relief.

108 See text accompanying notes $69-71$ supra. There is no question but that the state's interest is adverse. However, the decisive question was not confronted in Jackson, namely, whether a state interest had been injured with sufficient directness and severity so as to warrant judicial intervention.

$10 \pi$ The South Dakota court was sympathetic to the state's grievance and regretted that it could not "change the law to fit the needs of the occasion." 219 F. Supp. at 854. The Supreme Court has yet to rule on the question of suits brought by states under $\$ 36$ (c), but it has ruled against the Comptroller in suits brought by competitor banks. First Nat'l Bank v. Walker Bank \& Trust Co., 87 Sup. Ct. 492 (1966). Furthermore, it has had occasion to express its disapproval of the manner in which the Comptroller has pursued his policies. In Whitney Nat'l Bank v. Bank of New. Orleans \& Trust Co., 232.F.2d 290 (D.C. Cir. 1963), rev'd and remanded on other grounds, 379 U.S. 411 (1965), the branching question was raised, but the Court disposed of the case on another ground. However, the Court specifically reserved the question of review of the Comptroller's decisions. 379 U.S. at 423. In dissent, Mr. Justice Douglas expressly approved lower court review of the Comptroller: "This rule keeps the Comptroller from being a free-wheeling agency dispensing federal favors; and it gives some assurance that he will render principled decisions within the rule of law laid down by Congress." Id at 428. Observing that "the Comptroller candidly states that the new branch bank would be in business, flouting the new Louisiana law," Douglas asserted that under the ruling of the majority "the Comptroller can take the law into his own hands without restraint from anyone." Id. at 429-30.

${ }^{108}$ See notes 10-11 supra and accompanying text. One of Comptroller Saxon's objectives was to bring about substantive changes in state banking statutes which he considered outmoded, and the controversies he instigated were not inadvertent. Bratter, Fresh Air in the Comptroller's Office, Banking, July 1962, p. 45. Saxon lias stated: "Admittedly we are putting on the pressure all over the country. It is no accident; it is deliberate and calculated. We hope the states will pick up the ball ...." Id. at 130.

${ }^{109}$ See, e.g., Texas v. National Bank, 290 F.2d 229 (5th Cir.), cert. denied, 368 U.S. 832 (1961) (state's standing to sue not mentioned by the court). 


\section{Conclusion}

The branch banking conflict raises a difficult problem in federalism. Congress, having attempted to equalize the two competing forces within the dual banking system, established only the broad outline when it bound the Comptroller to observe state law. No check was provided to ensure the Comptroller's compliance with the standards set by the states in the event of conflict in the gray area of differing but plausible constructions of state law, nor was a remedy supplied to correct an arbitrary decision or abuse of discretion by the Comptroller. ${ }^{110}$ The states are now seeking to use section 36 (c), the instrument created to narrow the competitive advantage of state over national banks, for the purpose of restraining the federal instrumentalities from becoming the favored group. Since Congress has given statutory recognition to the interest of the state, the issue becomes when, if at all, the state's interest rises to such importance that the state itself will be enabled to challenge the decision of the Comptroller. ${ }^{111}$ Hopkins indicates that the protection of the judiciary may be invoked at some ill-defined point when the impairment of state institutions becomes objectionable. ${ }^{112}$ It is

\footnotetext{
${ }^{120}$ However, note that in some recent cases brought by private litigants, courts have granted rehef upon a finding that the Comptroller had acted beyond his discretion. See note 99 supra and accompanying text.

111 It is submitted that the sounder theory for an action by the state is standing to sue under the federal statute, rather than state enforcement of its own branching statute. See Hart, The Relations Between State and Federal Law, 54 Colum. L. REv. 489,529 (1954). Handler, himself a state official, concurs in this view. Handler, supra note 93, at 466 . Under the former theory any right asserted by the state would derive from the incorporation of state law within $\$ 36(\mathrm{c})$, and not from the failure of the federal government to pre-empt the field of branching by national banks. Accordingly, any litigation would occur in the federal courts, a procedure which does not allow the state to decide an issue of state law in its own forum. Nevertheless, this undesirable factor would be offset by a reduction in potential state interference with the regulation of the federal banking system, a result which can be assured by imposing a high burden of proof on the state to demonstrate abuse of discretion by the Comptroller. See note 113 infra.

112 Perhaps it can be argued that Fellows, as authority for the proposition that a state might have implied congressional authority to decide questions of state law that are adopted by reference in federal legislation, is somewhat qualified by the circumstances in which it arose. After all, the primary question at issue there was the constitutionality of the federal statute, and the ruling on the state's ability to bring the suit was merely a necessary step along the way. Similarly, the Hopkins rule is attenuated when it is applied in the branching situation, see note 93 supra and accompanying text. However, if the Court will protect the state's intercst in its chartered financial institutions from encroachment by the over-extension of congressional power, see note 92 supra and accompanying text, then it follows that this same interest may be shielded from infringement by arbitrary administrative power.
} 
submitted that the line be drawn and the state be allowed to sue where the court finds that the Comptroller's deviation from the state standard is sufficiently substantial ${ }^{113}$ and the harm to the state, actual or potential, ${ }^{114}$ is sufficiently grave as to outweigh the effect of potential interference with the administration of the federal banks. ${ }^{115}$ Obviously, each such determination must be made on the particular facts presented, and the doctrine of standing is well suited for the requisite judicial weighing and balancing.

It could be argued, however, that because the courts have allowed competitor banks to sue, there is sufficient restraint on the Comptroller and that to extend standing to the states would be a superfluous, perhaps harmful, act which would give rise to potential state interference with the operation of national banks. Yet this argument cuts both ways. If the courts are willing to curb the Comptroller when a competitor bank sues, how are they to justify giving him a free hand to defy the state statutory standards when a competitor bank does not happen to be within the trading area of a proposed national bank branch? The anomaly of the latter course is that whether the Comptroller may be restrained from acting arbitrarily turns upon the sheer fortuity that there is a properly located competitor bank which is willing, both from a financial and a public relations point of view, to bring suit.

Both cases exemplify the court's agility in applying traditional doctrines so as to reach the desired result.

${ }^{113}$ The standard of review of the Comptroller's ruling would properly be the same administrative standard that is now applied when the plaintiff is a competitor bank. See, e.g., Community Nat'1 Bank v. Saxon, 310 F.2d 224, 225-26 (6th Cir. 1962) (arbitrary, capricious, abuse of discretion, or otherwise not in accordance with law); Bank of Dearborn v. Saxon, 244 F. Supp. 394, 403 (E.D. Mich. 1965) (abuse of discretion); Peoples Bank-Trenton v. Saxon, 244 F. Supp. 389, 394 (E.D. Mich. 1965) (arbitrary, capricious, and abuse of discretion).

This standard of review should be sufficiently high to deter frivolous suits. The Comptroller's reading of state law is within his own discretion, of course, and thus is subject to change from one individual Comptroller to another. Former Comptroller Saxon, who was very aggressive in seeking bank expansion, intentionally put a strain on state limitations which he considered unduly restrictive, see note 108 supra, and conflict was high during his tenure. N.Y. Times, March 21, 1966, p. 49, col. 8.

214 If the injury is of the sort that will be judicially recognized once it has occurred, a mere threat of such injury should be sufficient to invoke the equitable powers of the court. No constructive purpose would be served, for example, by waiting for a large defection of state banks to occur before allowing the state to challenge the Comptroller's violations of the statute.

${ }^{115}$ In addition, to ensure that the state is not suing merely on behalf of private interests, a showing that there are no available competitor banks which could otherwise be plaintiffs might prudently be taken into account. 
Underlying the present legal conflict are fundamental questions of banking policy, which are beyond the scope and competence of the judicial power. As former Comptroller Saxon has maintained, it may be that legislation enacted during the Depression is no longer suited to contemporary needs and that those who resist reform are serving vested interests of their own. ${ }^{116}$ The issues of banking policy, however, have heavy political overtones, and thus any change is more properly left to the legislature. Nevertheless, once a legislative criterion is established, the judiciary must not remain inactive, or Congress' designs may be thwarted. In fact, under present conditions the congressional policy of competitive equality is in danger of being undermined if judicial recognition is not given to the states' interest in the branching decisions of the Comptroller.

\footnotetext{
${ }^{110}$ See Banking, May 1963, p. 157.
} 